\title{
Student Attendance At Campus Sporting Events: How Can We Get Them There?
}

\author{
Stephen B. Castleberry, University of Minnesota Duluth, USA
}

Stephen Espel, University of Minnesota Duluth, USA

\begin{abstract}
College student attendance at campus sporting events has been declining for a number of years with administrators looking for ways to reverse that trend. There are multiple reasons for the declining attendance and a multitude of possible solutions have been proposed. This case examines the situation for the football program at one mid-sized university, providing data from a representative cross section of the student population. Readers are tasked with making recommendations based on the data and to describe methods of evaluating the success of any changes.
\end{abstract}

Keywords: Student Attendance; Sporting Event; Campus; College Student

Suggested Courses for the Case: Marketing Management and Strategy; Marketing Research; Sports Marketing; Sports Management; Consumer Behavior; Strategic Management

\section{INTRODUCTION: THE ISSUE}

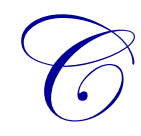

ollege student attendance at sporting events on their campus has been declining, and athletic directors across the country are looking for ways to get more students in the stadium (Fullerton, 2017; Southorn, 2017; Sullivan, 2017; Cohen \& Bachman, 2014). This is important as the students are the next generation of season ticket holders. The universities also rely on the students, once they become alumni, for donations to help support the teams (New 2014).

While this is creating a problem for the future, it also impacts current college budgets. Many universities rely on the revenues from the athletic program to not only fund athletics but also provide income and resources to the university, so a decline in attendance hurts the university as a whole (Davis, 2015).

The first step in getting more college students at games is discovering why they are not attending. As Oklahoma athletic director Joe Castiglione notes, "Interests and attitudes are changing so rapidly, it's not easy to quickly identify what we need to do" (Rovell, 2014). One of the most often-quoted potential reasons for lack of attendance is the increasing convenience of simply watching the game at home (Rishe, 2015). With the ability to watch multiple games in HD TV with no long lines to get food that is "over-priced," some students may be failing to find the benefits of going to a game in person (Rovell, 2014). While some schools do get money from TV deals, they are also losing money on ticket sales (Solomon, 2014). Quality of the opponent as well as whether the opponent is a key rival can impact attendance (Duffey, 2013). A number of schools have also identified the lack of quality cell phone and Wi-Fi service in the stadiums/arenas as potential concerns (Rittenberg, 2014). In some instances, such as at Auburn, the school's coordination of block seating for organizations is leading to unhappy students. The strict rules that go along with the block seating, such as being there one hour before and remaining for the entire game, may actually be discouraging students from wanting to attend (Tully, 2015). Students have also identified timing of the game, cost, weather, and traffic as deterrents (Grosbard, 2017; Hansen, 2017; Rishe, 2015).

Schools have tried a number of initiatives to get more students to the stadiums. For example, the Big Ten Conference has revised its in-stadium replay rules so that instead of just showing one or two replays, schools can show as many as they like and at slower speeds to mimic what one would view at home (Rittenberg, 2014). Some schools have also begun to attempt to provide fast, free Wi-Fi throughout their entire stadium, although this can be cost prohibitive. Colleges have also begun to implement live feeds and updates of other college football games at stadiums (Rittenberg, 
2014). Purdue has seen an increase in attendance of nearly $20 \%$, which they credit to a decrease in student ticket prices (Miller, 2015). In cases such as Texas A\&M, a new stadium was built to get students excited about a new environment (Davis, 2015). Schools like TCU (Texas Christian University) have begun to focus more on the experience than the amenities through studying the Disney Institute. Colleges are using a similar approach by creating more fan interaction and a more positive experience as a whole (Solomon, 2015). Other universities, like the University of Miami, have moved the student sections to better positions relative to the field (Rovell, 2014). Some schools are starting to create rewards programs to encourage student attendance. For example, Kansas State developed a student attendance reward program in which students gained points by attending home games. The points earned determined the student's ability to purchase tickets for the season's most sought-after home game. The promotion, however, was not successful, as other motivational factors, such as connection with the team, social aspects of attending, the level of competition, were found to be more important to students (Peetz, 2011). Finally, schools have begun to sell alcohol at games. To combat potential downsides, the University of Texas, among others, uses the high prices of alcohol as an attempt to discourage overconsumption by students (Tracey, 2015).

\section{A Case Example: University of Minnesota Duluth (UMD)}

UMD is a mid-sized (12,000 students) upper Midwestern university offering both undergraduate and graduate degrees. Due to modest enrollment declines, campus budgets have been slightly tightened. As a result, athletics has been tasked with increasing overall revenues and student engagement (both as a recruitment tool for prospective UMD students and as a retention tool to help keep UMD students enrolled and complete their degrees). Given budget tightening, there is very little money for new spending on fan engagement for football.

A total of five home football games are played each year. Early in the season, these tend to be Thursday or Saturday evening (the hours can vary), but later in the season, the last two games are played early Saturday afternoon.

Over the last several years, student interest in football games at UMD has been declining, and the school would like to understand why and determine how to reverse the trend. UMD conducted an online survey of 316 current undergraduate and graduate students, selected via a stratified sample technique. Students were provided anonymity, and attributes found by Ferreira and Armstrong (2004) to be important in influencing college students to attend college sports were included in the survey.

\section{GENERAL RESULTS}

Some of the most informative findings are reported here. The full database, accessible in both Excel and SPSS, which can be used to run additional analysis and crosstabulations, can be found here: https://z.umn.edu/3fsu

Table 1. Number of Games Attended Last Season

\begin{tabular}{c|c}
\hline Games Attended (out of 5) & Percentage of Students \\
\hline None & 35 \\
\hline 1 & 28 \\
\hline 2 & 16 \\
\hline 3 & 10 \\
\hline 4 & 5 \\
\hline 5 & 6 \\
\hline
\end{tabular}

Table 2. Top Factors Identified as "Very Important" or "Critical" for Student Attendance at Football Games

\begin{tabular}{l|c}
\multicolumn{1}{c|}{ Issue } & $\begin{array}{c}\text { Percentage of students who identified this as "Very } \\
\text { Important" or "Critical" }\end{array}$ \\
\hline Food price & 60 \\
\hline Food quality & 56 \\
\hline Restroom cleanliness & 51 \\
\hline Time of day game is played & 50 \\
\hline Quality of the stadium sound system & 48 \\
\hline
\end{tabular}

Scale points for these questions were not important, somewhat important, very important, and critical. 
Table 3. Top Factors Identified as "Not Important" for Student Attendance at Football Games

\begin{tabular}{l|c}
\hline \multicolumn{1}{c|}{ Issue } & $\begin{array}{c}\text { Percentage of students who identified this as "Not } \\
\text { Important" }\end{array}$ \\
\hline Strength of Wi-Fi signal & 63 \\
\hline Post-game traffic & 55 \\
\hline Pre-game traffic & 53 \\
\hline Availability of alcohol & 50 \\
\hline $\begin{array}{l}\text { The team enters the stadium, pregame, through an aisle of } \\
\text { students }\end{array}$ & 44 \\
\hline
\end{tabular}

Scale points for these questions were not important, somewhat important, very important, and critical

Table 4. Methods that Students Use to Stay Informed About UMD Football Games

\begin{tabular}{l|c}
\hline \multicolumn{1}{c}{ Method } & Percentage of students \\
\hline Email & 25 \\
\hline UMD athletics' webpage & 24 \\
\hline Twitter & 24 \\
\hline Facebook & 19 \\
\hline UMD pocket schedule & 14 \\
\hline Q & Table 4. Methods that Students Use to Stay Informed About UMD Football Games \\
\hline
\end{tabular}

Question allowed multiple responses.

Table 5. Top Reasons Students Do Not Attend More UMD Football Games

\begin{tabular}{l|c}
\hline \multicolumn{1}{c}{ Reason } & Percentage of students \\
\hline Weather & 49 \\
\hline Game time conflicts with personal schedule & 47 \\
\hline I prefer rivalry games or big match ups & 37 \\
\hline Atmosphere of the game & 20 \\
\hline Concessions are too expensive & 18 \\
\hline Question allowed multiple responses.
\end{tabular}

Table 6. What Would Motivate Students to Attend More UMD Football Games

\begin{tabular}{l|c}
\hline \multicolumn{1}{|c}{ Issue } & Percentage of students \\
\hline Increase size of student section & 31 \\
\hline Create new school traditions/cheers & 28 \\
\hline Rewards programs & 26 \\
\hline Promotional giveaways & 25 \\
\hline More in-game entertainment & 24 \\
\hline Better weather conditions & 22 \\
\hline
\end{tabular}

Question allowed multiple responses.

Table 7. Net Promoter Score: Student Responses to

"How Likely is it that You Would Recommend a UMD Football Game to a Friend?"

\begin{tabular}{|c|c|}
\hline Net Promoter Grouping & Percentage of students \\
\hline Detractors (scored 0-6) & 66 \\
\hline Passives (scored 7-8) & 26 \\
\hline Promoters (scored 9-10) & 8 \\
\hline
\end{tabular}


Table 8. Sports Fan Segments of Student Respondents (of those who attend games)

\begin{tabular}{l|c}
\hline \multicolumn{1}{|c}{ Segment } & Percentage of students \\
\hline Socialites (go to be with friends) & 57 \\
\hline Patriot (proud of school) & 17 \\
\hline Appreciator (watch athletic skills) & 12 \\
\hline Player (used to play football myself) & 12 \\
\hline Looker (watch attractive people) & 2 \\
\hline
\end{tabular}

For information on these segments see Fullerton (2017)

\section{Males Compared with Females}

Cross-tabulation analyses were performed of males versus females to compare results. Only statistically significant differences are reported here and in subsequent sections of this case. Males and females attended very similar percentages of games. However, $49 \%$ of females credited attending games to the social aspect compared to $34 \%$ of males. A little over $13 \%$ of males claimed the availability of alcohol was critical, compared to $3 \%$ of females. The location of the alcohol tent was critical to $19 \%$ of males as compared to $5 \%$ of females. For males, $41 \%$ found promotional giveaways to be of no importance, compared to $33 \%$ of females. When ranking importance of tailgating, only $9 \%$ of females claimed tailgating to be critical, as compared to $17 \%$ for males. A total of $47 \%$ of females considered food selection very important or critical, while $37 \%$ of males thought the same. Females found restroom cleanliness to be very important (46\%) compared to males (34\%). Males were also more interested in having cheerleaders at games compared to females (51\% vs. $24 \%)$.

\section{Underclassmen Compared with Lowerclassmen}

The responses of upperclassmen (juniors and seniors) were compared to lowerclassmen (freshman and sophomores). A total of $46 \%$ of lowerclassmen credited the social aspect of games as their reason for attending football games compared to $32 \%$ of upperclassmen. Upperclassmen are more likely to not attend football games (38\% vs. $26 \%$ of lowerclassmen). Not surprisingly, given the legal drinking age, 59\% of lowerclassmen considered alcohol availability as not important, as compared to $35 \%$ of upperclassmen.

\section{On-Campus Students Compared with Students Who Live Off-Campus}

A full $38 \%$ of students who live off-campus said they do not attend UMD home football games, compared to $21 \%$ of students who live on-campus. About $58 \%$ of on-campus students deemed the availability of alcohol as not important. About $56 \%$ of on-campus students consider availability of parking to be "not important," compared to $33 \%$ of offcampus students. Off-campus students also felt that traffic before and after games was an important consideration when deciding to attend a football game.

\section{CASE QUESTIONS}

1. What recommendations would you make for increasing the number of students at football games at UMD?

2. Compare the Net Promoter Score (NPS) for this Football program with other NPS scores shown in your textbook or by using a web search.

3. The data provided in this case came from a survey of selected students. What other marketing research tools might be used to learn more about student preferences and experiences as fans at college football games?

4. Assume you make changes to the football games to try and increase fan interest and attendance. How would you assess whether the changes are having a positive impact on fans? 


\section{TEACHING NOTES}

Teaching notes, including notations of what UMD actually adopted, are available from the senior author.

\section{ACKNOWLEDGEMENT}

Special thanks to Gina Grensing for her assistance in editing and revising this paper.

\section{AUTHOR BIOGRAPHIES}

Stephen B. Castleberry is a professor of marketing and business ethics in the Labovitz School of Business and Economics at the University of Minnesota Duluth. His research interests include sports marketing and business ethics.

Stephen Espel is a recent undergraduate student from the Labovitz School of Business and Economics at the University of Minnesota Duluth and is now a Portfolio Evaluation Group Associate at Fisher Investments.

\section{REFERENCES}

Cohen, B., \& Bachman, R. (2014). Missing from major college stadiums: The students. Wall Street Journal - Eastern Edition, (August 28), A1-A2.

Davis, B. (2015). Eyes on Texas: Ticket sales continue creeping in the wrong direction. Austin American-Statesman, September 24. Retrieved from http://www.hookemplus.com/columns/eyes-on-texas-ticket-sales-continue-creeping-in-the-wrongdirection/

Duffey, K. (2013). The real reason college football live game attendance is down. Saturday Down South, October 3. Retrieved from https://www.saturdaydownsouth.com/2013/college-football-live-game-attendance/

Ferreira, M., \& Armstrong, K. L. (2004). An exploratory examination of attributes influencing students' decisions to attend college sport events. Sport Marketing Quarterly, 13(4), 194-208.

Fullerton, S. (2017). Sports Marketing, 3rd Edition, Chicago: Chicago Business Press.

Grosbard, A. (2017). How SMU is trying to fix its attendance problem. SportsDay, October 31. Retrieved from https://sportsday.dallasnews.com/college-sports/smumustangs/2017/10/31/smu-trying-fix-attendance-problem

Hansen, G. (2017). Arizona Wildcats are winning, but where are the fans? Arizona Daily Star, October 31. Retrieved from http://tucson.com/sports/arizonawildcats/article_d8381233-15ce-5791-8470-

$748038 \mathrm{~d} 13 \mathrm{~b} 24 . \mathrm{html}$ ?utm_source=twitter\&utm_medium=social\&utm_campaign=share $\& \mathrm{id}=201408$

Miller, A. (2015). Attendance on the rise at Ross-Ade stadium. WISHTV, September 25. Retrieved from http://wishtv.com/2015/09/25/attendance-on-the-rise-at-ross-ade-stadium/

New, J. (2014). Empty seats now, fewer donors later? Inside Higher Ed, September 24. Retrieved from https://www.insidehighered.com/news/2014/09/11/colleges-worry-about-future-football-fans-student-attendancedeclines

Peetz, T. B. (2011). Marketing the 'big game': Developing a student rewards program in college basketball. Sport Marketing Quarterly, 20(2), 115-121.

Rishe, P. (2015). Examining the decline in college football attendances: Do remedies exist? Forbes, December 22. Retrieved from https://www.forbes.com/sites/prishe/2015/12/22/examining-the-decline-in-college-football-attendances-doremedies-exist/\#10b594a77df4

Rittenberg, A. (2014). Attendance challenges big deal for B1G. ESPN, February 17. Retrieved from http://www.espn.com/blog/bigten/post/_id/95953/attendance-challenges-big-deal-for-b1g

Rovell, D. (2014). Will next generation of fans show up? ESPN, February 17. Retrieved from http://www.espn.com/collegefootball/story/_id/10458047/next-generation-ticket-holder-concern-students-show-college-football-games

Solomon, J. (2015). College football attendance making rare increase early in 2015. CBSSports.com, October 6. Retrieved from https://www.cbssports.com/college-football/news/college-football-attendance-making-rare-increase-early-in-2015/

Solomon, J. (2014). College football's fight to keep its next generation of fans. CBSSports.com. Retrieved from https://www.cbssports.com/college-football/news/college-footballs-fight-to-keep-its-next-generation-of-fans/

Southorn, D. (2017). Boise State football tickets generate less revenue every year. 'I'm concerned,' AD says. Idaho Statesman, October 30. Retrieved from http://www.idahostatesman.com/sports/college/mountain-west/boise-state-university/boisestate-football/article181643311.html

Sullivan, T. (2017). Even at rivalry games, empty seats are all too common. Louisville Courier Journal, (Nov 25). Retrieved from https://www.courier-journal.com/story/sports/college/kentucky/2017/11/25/rivalry-games-empty-seats-collegefootball/881120001/ 
Tracy, M. (2015). Beer here! Beer here? The New York Times, October 8. Retrieved from https://www.nytimes.com/2015/10/09/sports/ncaafootball/beer-alcohol-college-football-west-virginia.html

Tully, C. (2015). New block seating system receives mixed reviews. The Auburn Plainsman, September 23. Retrieved from http://www.theplainsman.com/article/2015/09/new-block-seating-system-receives-mixed-reviews.

"What is Net Promoter?" (2017). Satmetrix Systems, Inc. Retrieved from https://www.netpromoter.com/know/ 